decision of problem of increase of theoretical level of biological education in foreign and home pedagogical theories. The conducted analytical research revealed that the problem of raising the theoretical level of biological education in foreign and domestic pedagogical theory still remains urgent; it is more relevant for the domestic method of teaching biology than for the corresponding method of far abroad; scientists associate the increase of the theoretical level of teaching biology with the purposeful formation of theoretical biological knowledge, understanding of the leading generalizations of life science in students of general secondary education; some aspects of the process of formation of theoretical knowledge in biology are considered, in particular, the use of the structure of the theory for constructing the content of biological education and systematization of students' knowledge about living nature.

Key words: theoretical knowledge of biology, foreign experience of knowledge formation, domestic experience of knowledge formation, theoretical thinking, creative abilities, structure of theory, components of theoretical knowledge

Дата надходження статті: 15.12.2020 p. Рецензент: доктор педагогічних наук Коробова I. В.

UDC 373.5.016:81

DOI https://doi.org/10.37915/pa.vi47.147

Lebedeva N. M.*, orcid.org/0000-0002-6297-106X

Frantsuzova K. S., orcid.org/0000-0002-0959-2669

\title{
LANGUAGE LEARNING STYLES IN TEACHING ENGLISH LANGUAGE: LINGUODIDACTIC STUDY ASPECT
}

The article presents various approaches to studying the problem of language learning styles in modern linguodidactics, explains the reasons for their popularity in the world practice of teaching foreign languages and why they are widely accepted and popularized by British and American scientists. The authors consider and interpret in detail the main types of language learning styles, indicating their advantages and disadvantages, and how they can be used to improve the quality of teaching a foreign language in high school. The material demonstrates the role of learning styles in teaching foreign languages. The issue of differentiating the language learning styles of the teacher and the student also deserves attention.

The problem of language learning styles of teaching English in high school, has acquired special relevance due to the need for modern students to develop communication skills in various social spheres. The term "language learning styles" is used to describe a concept that involves the process of the students receiving new foreign language information and developing their ability to relay it adequately in the process of communication.

The authors analysed the basic principles of language learning styles in modern linguodidactics and revealed the possibilities of their specific application in the methods of teaching English in high school. Relationships have been established between different approaches to learning language styles. There have been determined methods for forming a "sense of style" corresponding to a communicative situation.

In a broad sense, language learning styles are considered in the context of general principles of teaching a foreign language, but the need for differentiated and personally oriented learning is emphasized. The scientists proceed from the fact that the choice of learning styles provides for taking into account the level of psychological and communicative training of students, in particular the degrees

*C Lebedeva N. M.

*C Frantsuzova K. S.

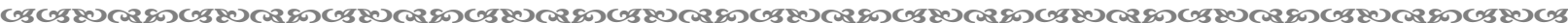


of formation of their language and speech skills in English, as well as the intellectual level, age personality traits, processes of memory, imagination, thinking.

The researchers developed proposals for the use of language learning styles in the practice of English instruction in high school, and also identified the prospect of further research in this area.

Key words: teaching methodology, English language, linguodidactics, language learning styles, reception, communication.

The statement of the issue. The article dwells upon the problem of language learning styles and their typologies as general approaches to teaching foreign languages that students use in acquiring a new language. These language learning styles are those general patterns that give overall direction to learning conduct.

Information about language learning styles in valid without regard to what the student's first language is. The theory holds that "styles" is more general term being "an individual's" preferred, habitual and natural way of processing, retaining and absorbing new information, skills. They appear to be relatively stable and be developed by individuals regardless of the subject being studied or the skill being mastered.

Learning styles refer to the concept which includes process and perception of information in different ways. There are many factors that lead to different approaches in interpretation of learning styles. These factors include personality, ability to process information, self-efficacy, sensory, psychological peculiarities of individuals.

The scientists have characterised different learning styles using their own approaches. Some of them elect perceptual styles: the visual, tactile, auditory and kinaesthetic. Others prefer cognitive styles distinguished between field-dependent and field-independent learners. Some researchers pay attention to personality styles of reflectivity and impulsiveness.

The analysis of relevant research. The theory of language learning styles has been developed by the British and American authors. No coherent theory emerged from their studies. The idea governing this approach is in the statement that styles is more general term being "a person's" preferred, natural and habitual way of processing, retaining and absorbing new information, skills. These styles appear to be relatively stable and be developed by individuals regardless of the subject being studied or the skill being mastered (B. Cerbin, N. Chick, R., F. Coffield, D. Mosely, E. Hall and K. Ecclestone, Dunn and S. Griggs, N. Fleming and C. Mills, A. Grasha and S. Reichmann, M. Lepper, C. Miller, T. Fitch and J. Marchall, H. Pashler, M. McDaniel, D. Rohrer and R. Bjork, P. Paterson, J. Rosbottom, K. Willings [2-6; 8-10; 12; 13]).

The authors synthesize researches on language learning style from different parts of the world on the main variables affecting language learning styles: the specific behaviours or thoughts learners use to enhance their language learning and the general approaches to learning language. Such factors influence the learner's ability to study a particular instructional framework. Learning styles are generally operated on a continuum or on multiple, interesting continua.

Thus many scientists have made significant contributions to the various stages of developing methodology of language learning styles.

The purpose of the article is to analyse linguodidactical views on language learning styles and their application in the pedagogical process in schools and the educational institutions. The tasks are: 1) to present different approaches to the problem of language learning styles, give reasons why language learning styles have gained great popularity and why this approach is widely accepted by foreign scientists; 2) to list the main domains of learning styles and give the examples of each domain; 3) to recognise the implication of these language learning styles of teaching; 4) to demonstrate the role of language learning styles in the theory of methods of teaching.

The body of the research. The term "language learning styles" is used to denote how learners gather, shift through, interpret, organise, "store" information for further use and come

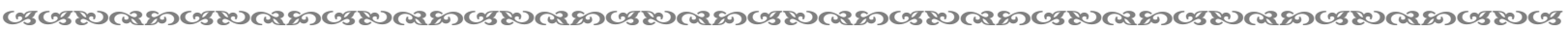


to conclusions about. As spelt out in VARK (one of the most popular language styles inventories) these styles are often categorised by sensory approaches: visual, aural, verbal (reading, writing and kinaesthetic) [4].

There exist 70 different learning styles schemes [2, p. 8-9], most of which are supported by thriving industry dedicated to publishing different styles tests, professional development workshops and guidebooks for teachers, educators [9, p. 103-119].

The fundamental idea of language learning styles is the same as any individual has learning style (sometimes called "a preference") and he learns best when information is presented to him in this style.

For example, the visual learners could learn any topic better if it is given graphically through the other kinds of visual images; kinaesthetic learners would learn more effectively if they could do bodily movements in learning process etc.

In spite of the fact the literature on learning styles is enormous the scientists found no evidence supporting the idea that instruction is the best provided in a format that matches preference of the learner [9]. Many of those studies suffered from weak research design. Others with effective experimental design achieved the results, that firmly contradict the popular assumption about language learning styles.

The scientist explains the reasons why language learning styles have gained such popularity. On the one hand people like to identify themselves by stereotypes. They find quick ways of understanding each other under different social conditions. This approach appeals to the idea that learners should be recognised as "unique individuals". Teaching to different language learning styles means that all the people have potential to study easily and effectively if only the instruction is tailored to their personal learning styles.

On the other hand there is another reason why this approach is widely accepted. It resembles the term of metacognition or process of thinking about somebody's thinking (for example, asking the students to describe which study tragedies or conditions of their previous exam worked for those students and which didn't improve their studying on the next exam).

Metacognition is focused on evaluating, planning and monitory any way of "thinking about thinking" and does nothing in order to connect somebody's abilities or identity to any singular method of learning.

There is however something one "can take away from these different approaches to learning - not based on the learner, but instead on the content being learned" [12]. The scientists point that the differences, identified by labels auditory, visual, kinaesthetic, reading or writing are more appropriately related to the nature of discipline.

$\mathrm{H}$. Pashler and colleagues agree that the optional instructional method is likely to vary across disciplines [9]. In other words: it makes disciplinary sense to include kinaesthetic activities in anatomy and sculpture courses, writing, reading activities, in history and literature courses, in music, auditory activities, in speech courses and foreign language. It includes topic matter without limiting potential abilities of learners.

This concept that people learn best when taught through their individual language learning style is very popular. That is why such theories are playing a bigger part in any presentation of teaching methods.

The most prominent theories propose to divide language styles descriptions into visual learners, auditory learners, kinaesthetic and mixed type. Visual learners: in learning context they learn best through seeing. Flash cards, videos, diagrams and charts work well for the students. Auditory learners: in a learning context they study best through listening. They also like to read and prefer spoken instructions and explanations. They are good at telling jokes and stories; memorise facts and information easily, and discuss and exchange it easily. Kinaesthetic learners: in a learning context they learn best through moving, doing and touching. They need to have "hands-on-experience" assimilate learning. They are good at drawing and perform well in role plays and activities. Mixed type: in a learning context these learners are very lucky as they can adapt to any learning situation. They benefit from visual stimuli such as diagrams,

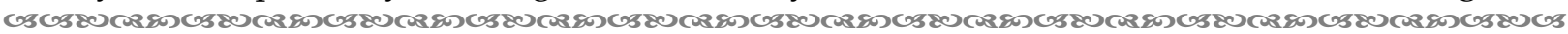


charts pictures. They use visualisation to remember things and pick up meaning from body language. They also enjoy moving around [1].

The abbreviation VARK is used to describe main modalities of learner's studying. They were described by Neil D. Fleming, C. Mills in 1992. These authors created the accompanying questionnaire for the educators to give learners help them, understand and identify their personal learning likings.

The best approach to date for interpreting above researchers is suggested by VARK model by Neil Fleming (1981) [4] based on the sensory channels. According to it learners fall into four categories: auditory, visual, reading/writing, kinaesthetic [4].

Let's go into detail and examine all the stages of the theory.

1. Visual are those learners who best analyse and synthesise information when it is presented to them in a graphic description of meaningful symbols. They may apply charts, diagrams, clips, pictures images, drawings and other visualisations of informative hierarchy, but not necessarily to photographs and videos. The visual learners get information best when visual material is given in graphs, maps, tables and charts.

2. Auditory/aural learners are more successful when they are given possibility to hear the information presented to them verbally.

3. Reading/writing learners: students who work best in reading (or writing) modality demonstrate a strong studying preference for written words. It includes the written information that presented in class in form of hands out and slides or written assignments.

4. Kinaesthetic learners "are hands-on, participatory learners who need take some physically active role in learning course to achieve their best learning outcomes. They are also called "tactile learners". Tactile learners tend to engage all of their senses in the process of learning" [4].

There exist numerous ways of characterising styles. M. Christon differentiates cognitive style (field independent versus field-dependent, global versus analytic, global versus reflective, kinaesthetic versus reflective) and personality styles (left train dominance tolerance of ambiguity versus right brain) [7].

In relation to language styles, Keith Willing [13] presents a new classification of the learning styles:

- identified - four major styles: communicative, analytical, authority-oriented and concrete.

- communicative - the students like to learn by watching, listening to native speakers, talking in English, watching TV in English, learning and hearing new words and learning by conversation.

- analytical - the students like to study grammar, studying English book, studying alone, finding their mistakes, and working on problems set by the teacher.

- authority-oriented - they like the teacher to explain new information having their own textbooks, writing everything in their notebooks, learning by reading, learning new words/phrases by seeing them and studying grammar.

- concrete - the students like games, pictures, films, video, talking in pairs and practicing English outside class.

There are a number of cognitive theories including A. Grasha and S. Riechmann (1974). They formulated the Grasha-Reichmann Learning Style Scale [5]. According to this theory, students can be: independent, collaborative, dependent, participant, competitive, avoidant. The Grasha-Riechmann student learning styles scale "was developed to measure learning preferences of adults undergraduates and above. It measures cognitive and affective behaviours of learners instead of perceptual" [5]. To define the learner's style they offer them the test at the first lesson. This test will help to identify student according to Grasha-Reichmann Learning Style Scale.

In this paper we can focus our attention to the method of teaching suggested by Rasool Somji. He presents eight dominant learning styles though we are not sure that all of them may

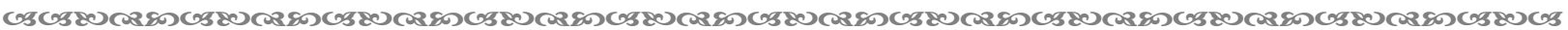


be completely effective in teaching. He adds to the visual and aural learners styles another six ones [11]: verbal, social, logical, physical and tactile, solitary, naturalist.

Further we will make an attempt to analyse them.

Verbal Learners. They acquire oral skills and habits in speech and writing, listening and speaking. Role-playing quizzes are widely included in practice. Audio is also used to support a new introduction of a material.

Social Learners. It implies interactive communication with other learners (group work, a role-play, discussion of the stories, concept, ideas).

Logical Learners prefer analysing using logic and reasoning. They classify and categorise new information and solve problems with members (solution of the tasks, interpreting abstract information, critical thinking, statistics and facts).

Physical and Tactile Learners. Practical learners get information in the process of doing something. They put their learning into practice (physical exercises, standing and walking activity, writing, role-playing).

Solitary Learning. Learning by themselves and self-study (asking questions, individual problem-solving exercises, links between what has been previously learned and new concepts).

Naturalist Learners. The learners get/receive material by working with and experiencing nature. These students study by comparing patterns with nature and using scientific logic for understanding (experiments and link between the concept of nature and objects of learning).

Besides the student's learning style we can present the common teacher's style (lecture style) which we can represent in the table 1.

Table 1

Student's styles vs Teacher's style

\begin{tabular}{|l|l|}
\hline \multicolumn{1}{|c|}{ Student's styles } & \multicolumn{1}{c|}{ Teacher's style/lecture style } \\
\hline self-directed & communicative \\
\hline self assessing & authority-oriented, or lecture style \\
\hline self questioning & concrete \\
\hline using directed or selective thinking & analytic \\
\hline using discourse & demonstrator, coach style \\
\hline critiquing & facilitator, or activity style \\
\hline revising & delegator or group style \\
\hline summarizing & hybrid, or blended style \\
\hline induction & \\
\hline imagery & \\
\hline making influence & \\
\hline $\begin{array}{l}\text { using inference (developing the ability } \\
\text { to use reference material) }\end{array}$ & \\
\hline
\end{tabular}

Taking into account the above mentioned theoretical and factual material on learning styles we should state that studies of language styles initially developed as a result of some interest in personal differences. These subjects were very much in vogue with investigatory psychology, enjoyed a continuing popularity, but have past regrettably from vogue since then due to the society is changed focus or an evolution of professional interest, studying is both a product and a process. The product is observable as a (relatively) permanent change in behaviour (or potential behaviour). The process is holistic, adaptive and future focused; affecting an personal's affective, cognitive, moral and social volitional skills. The process is noticeable in improved ability of a person to adapt to the environmental stimuli.

Conclusions. Despite the great number of scientific researches touching the problems of learning language styles over the last several years, there is no pure evidence that one style is generally better than another. The reason is that we could not do very much in order to alter 
how we prefer to study. What is more important in influencing some rate of progress in studying the language are strategies that are applied in the particular learning situation.

Undoubtedly the paper contributes to interactional methodology. It is important to emphasize that language styles of individual students can work together with or conflict a given interactional methodology. If there is a harmony between the student (in terms of style) and the combination of materials and interactional methodology then the learner is likely feel confident and to perform well.

In other words language styles are among the factors that help to determine how - and how well the students learn a foreign language.

There is a general belief that such a focus helps teachers and students become more effective learners and facilitates the activation of a learner-centered philosophy.

In all discussions so far a foreign language is regarded the language which is studied in that environment where it is not primary vehicle for everyday interaction and where jump in that language is restricted.

Perspectives of our following research lie in learning styles that has focused on a wide variety of questions and issues. These include the relationships between the preferences of the chosen learning style and other learner's characteristics such as educational level, ethnic background and first language; the issue of whether effective learners share certain style and whether effective learners share attitudes towards, and patterns of language practice and use in speech.

\section{Bibliography:}

1. Коваленко О., Шаленко О. Післядипломна педагогічна освіта вчителів іноземних мов. Посібник для вчителів-слухачів курсів фахового удосконалення / Британська Рада в Україні; Міністерство освіти і науки, молоді та спорту України. Київ, 2012. 385 с.

2. Coffield F., Mosely D., Hall E., Ecclestone K. Learning Styles in Pedagogy in Post-16 Learning. A Systematic and Critical Review. London: Learning and Skills Research Centre, 2004. P. 8-9.

3. Dunn R., Griggs S. Learning Styles: Quiet Revolution in American Secondary Schools. New York, USA: St. John's University, 2010. P. 40-42.

4. Fleming N., Mills C. The VARK Model Educationline. 2019. URL: https://educationonline.ku.edu/community/4-different-learning-styles-to-know

5. Grasha A., Reichmann S. Learning Style a Scales (GRLSS). 2015. URL: https://elearningindustry.com/learning-style-diagnostics-grasha-riechmann-student-learning-styles$\underline{\text { scale }}$

6. Lepper M. R. Motivational Consideration in the Study of Instructions. Cognition and Instruction. Lawrence Erlbaum Associates, Inc., 1988, 5 (4). P. 289-309.

7. Mardel Christian and Education. Home Schoollife : Overview of Learning Styles. The Kinesthetic Learner. 2020. URL: https://www.youtube.com/watch?v=TXe1KPJCh5c

8. Miller C. A., Fitch T. L., Marshall J. L. Locus on Control and At-Risk Youth: a Comparison of Regular Education of High School Students and Students in Alternative Schools. Education, 123 (3), 2003. P. 548-552.

9. Pashler H., McDaniel M., Rohrer D., Bjork R. Learning Styles: Concepts and Evidence. Psychological Science in the Public Interest. 9.3, 2009. P. 103-119.

10. Paterson P., Rosbottom J. Learning Styles and Learning Strategies. Department of Information Science. University of Portsmouth, 1995. Volume 1. Number 1. P. 3-5.

11. Somji Rasool. Teaching Strategies for the 8 Different Learning Styles. Virtual Speech. VR Platform. 2018. URL: https://virtualspeech.com/blog/teaching-strategies-different-learning-styles

12. William C. Understanding Learning Styles: A Conversation With Dr. Bill Cerbin. Interview With Nancy Chick. UW Colleges Virtual Teaching and Learning Center, 2011. URL: https://sites.google.com/a/gapps.uwc.edu/vtlc/home/programs/podcasts/learningstylescerbin

13. Willings K. Learning Styles and Strategies. 2019. URL: https://skyteach.ru/2019/03/19/learning-stylesand-strategies/ 


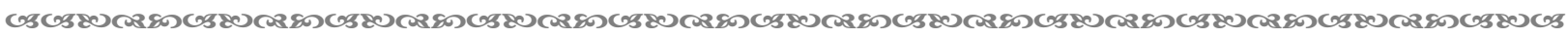
ПЕДАГОГІЧНИЙ АЛЬМАНАХ. - 2021. - ВИПУСК 47

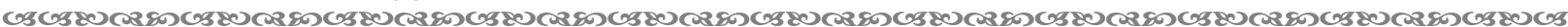

\section{References:}

1. Kovalenko, O., \& Shalenko, O. (2012). Pislyadyplomna pedagogichna osvita vchyteliv inozemnyh mov: posibnyk dlya vchyteliv-sluhachiv kursiv fahovogo udoskonalennya [Postgraduate pedagogical education of foreign language teachers: manual for Vocational Training Teachers]. Kyiv [in Ukrainian].

2. Coffield, F., Mosely, D., Hall, E., \& Ecclestone, K. (2004). Learning Styles in Pedagogy in Post-16 Learning. A Systematic and Critical Review. London: Learning and Skills Research Centre [in English].

3. Dunn, R., \& Griggs, S. (2010). Learning Styles: Quiet Revolution in American Secondary Schools. New York, USA: St. John's University [in English].

4. Fleming, N., \& Mills, C. (2019). The VARK Model Educationline. Retrieved from https://educationonline.ku.edu/community/4-different-learning-styles-to-know [in English].

5. Grasha, A., \& Reichmann, S. (2015). Learning Style a Scales (GRLSS). Retrieved from https://elearningindustry.com/learning-style-diagnostics-grasha-riechmann-student-learning-stylesscale [in English].

6. Lepper, M. R. (1988). Motivational Consideration in the Study of Instructions. Cognition and Instruction. Lawrence Erlbaum Associates [in English].

7. Mardel Christian and Education. (2020). Home Schoollife: Overview of Learning Styles. The Kinesthetic Learner. Retrieved from https://www.youtube.com/watch?v=TXe1KPJCh5c [in English].

8. 8. Miller, C. A., Fitch, T.L., \& Marshall, J. L. (2003). Locus on Control and At-Risk Youth: a Comparison of Regular Education of High School Students and Students in Alternative Schools. Education, 123(3) [in English].

9. Pashler, H., McDaniel, M., Rohrer, D., \& Bjork, R. (2009). Learning Styles: Concepts and Evidence. Psychological Science in the Public Interest, 9.3 [in English].

10. Paterson, P., \& Rosbottom, J. (1995). Learning Styles and Learning Strategies. Department of Information Science. University of Portsmouth, 1, 1 [in English]

11. Rasool, S. (2018). Teaching Strategies for the 8 Different Learning Styles. Virtual Speech. VR Platform. Retrieved from https://virtualspeech.com/blog/teaching-strategies-different-learning-styles [in English].

12. William, C. (2011). Understanding Learning Styles: A Conversation With Dr. Bill Cerbin. Interview With Nancy Chick. UW Colleges Virtual Teaching and Learning Center. Retrieved from https://sites.google.com/a/gapps.uwc.edu/vtlc/home/programs/_podcasts/learningstylescerbin [in English].

13. Willings, K. (2019). Learning Styles and Strategies. Retrieved from https://skyteach.ru/2019/03/19/learning-styles-and-strategies/ [in English].

Пебедєва Н. М., orcid.org/0000-0002-6297-106X

Франичзова К. С., orcid.org/0000-0002-0959-2669

\section{МОВНІ СТИЛІ НАВЧАННЯ У ВИКЛАДАННІ АНГ ЛІЙСЬКОЇ МОВИ: ДІНГВОДИДАКТИЧНИЙ АСПЕКТ}

У статті представлені різні підходи до вивчення проблеми мовних стилів у сучасній лінгводидактиці, пояснюються причини їх популярності у світовій практиці викладання іноземних мов $i$ чому вони широко прийняті $i$ популяризуються британськими та американськими вченими. Автори детально розглядають та інтерпретують на прикладах основні види мовних стилів навчання ("language learning styles"), вказуючи на їхні переваги та недоліки, і як вони можуть бути використані для покращення якості викладання іноземної мови у середній школі. У ході викладеного матеріалу демонструеться роль "language learning styles" у методиці викладання іноземних мов. Заслуговуе на увагу питання про розмежування понять "language learning styles" викладача та учня.

Проблема "language learning styles" у викладанні англійської мови у середній школі набула особливої актуальності у зв'язку з необхідністю формування у сучасних учнів навичок комунікації в різних соціальних сферах. Термін "мовні стилі навчання» ("language learning styles") використовуеться для опису концепта, щзо включае процес рецепцій школярами нової іншомовної інформацї̈ та вироблення у них уміння адекватно ї̈ ретранслювати у процесі спілкування.

03 
Авторками проаналізовано основні принциипи "language learning styles" у сучасній лінгводидактиці та розкрито можливості конкретного застосування їх у методиці навчання англійської мови у середній школі. Встановлено взаємозв'язки між різними підходами до вивчення мовних стилів. Визначено методи формування «відчуття стилю», відповідного комунікативній ситуації.

У широкому розумінні "language learning styles" розглядається у контексті загальних принциипів навчання іноземної мови, проте акцентуеться необхідність диференційованого та особистісно зорієнтованого навчання. Авторки виходять з того, що вибір стилів навчання передбачае врахування рівня психологічної і комунікативної підготовки учнів, зокрема ступенів сформованості їхніх мовних та мовленневих навичок з англійської мови, а також інтелектуального рівня, вікових особистісних рис, процесів пам'яті, уяви, мислення.

Авторки розробихи пропозиції щзодо використання "language learning styles" у практицุi навчання англійської мови у середній школі, а також визначили перспективу подальших досліджень у ціий галузі.

Ключові слова: методика навчання, англійська мова, лінгводидактика, мовні стилі навчання ("language learning style"), pец̧епц̧ія, комунікацุiя.

Дата надходження статті: 24.12.2020 p. Рецензент: доктор педагогічних наук Чумак $\Lambda$. В.

\section{У,ДК 37(082):502/504 \\ DOI https://doi.org/10.37915/pa.vi47.154}

Чайковська Г. Б. , orcid.org/0000-0003-4614-3843

\section{ОСВІТА ДЯЯ СТАЯОГО РОЗВИТКУ В СУЧАСНІЙ ПОЧАТКОВІЙ ШКОЯІ: УМОВИ ВПРОВАДЖЕННЯ}

у статті розглянуто проблему реалізації освіти для сталого розвитку в умовах реформування вітчизняної освіти та з урахуванням реалій $i$ потреб сьогодення. Зокрема проаналізовано та обьрунтовано педагогічні умови реалізациї цุілей освіти для сталого розвитку в навчанні учнів молодшого шкільного віку. Наголошено на необхідності оновлення змісту типових освітніх програм для початкової иколи контентом сталого розвитку та освіти для сталого розвитку, у т.ч. природничої, громадянської та історичної, соцізальної таздоров'язбережувальної освітніх галузей, що реалізуеться в межах інтегрованого курсу «Я досліджую світ». Доведено, щзо така інтеграція відображае ідеї та приниции сталого розвитку, грамотно поєднуе його ключові компоненти та сприяе формуванню в учнів початкової школи багатогранних, інтегрованих компетентностей.

Установлено, щцо важливою педагогічною умовою реалізацій цъілей освіти для сталого розвитку є використання принцииів педагогіки емпауерменту (мотивації і натхнення до дії). 3'ясовано, щзо основним методом цзієї концепції є партнерство, побудоване на основі активної суб'єкт-суб'єктної взаємодії учасників освітнього процесу.

В реалізацї̈ циілей освіти для сталого розвитку в освітньому процесі початкової школи необхідним вважаємо формування в учнів таких навичок: упевненість у собі, ораторські здібності, комплексне розв'язання проблем, уміння працювати в команді, вирішення конфліктів, емоційна компетентність, креативність, уміння домовлятись, когнітивна гнучкість тощо.

Обьрунтовано важливість забезпечення інтерактивності освітнього середовища початкової школи як умови реалізації ицілей освіти для сталого розвитку шляхом використання

*C) Чайковська Г. Б.

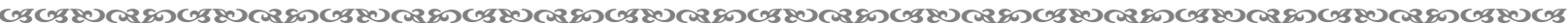

